Received $\quad 03.08 .2016$ Reviewed 10.11.2016 Accepted 15.11.2016

A - study design

B - data collection

C - statistical analysis

D - data interpretation

$\mathbf{E}$ - manuscript preparation

F - literature search

\title{
An experimental study on the grape orchard: Effects comparison of two irrigation systems
}

\author{
Sharad J. KADBHANE ${ }^{\text {ABCDEF } \bowtie}$, Vivek L. MANEKAR ${ }^{\text {ADE }}$
}

Sardar Vallabhbhai National Institute of Technology, Surat, Gujarat, India; e-mail: sharad_kadbhane@rediffmail.com, vivek_manekar@yahoo.co.in

For citation: Kadbhane S.J., Manekar V.L. 2017. An experimental study on the grape orchard: Effects comparison of two irrigation systems. Journal of Water and Land Development. No. 32 p. 41-51. DOI: 10.1515/jwld-2017-0005.

\begin{abstract}
Table grape (Vitis vinifera cultivars) is a major cash crop in the Nashik district of India, which requires irrigation water throughout the year as per demand instantly. Canal irrigation is the adopted irrigation systems in the study area, but canal irrigation has got several serious disadvantages, such as mismatching rotation schedules and crop water demands, water allotment system and restrictions on the use of efficient irrigation methods. The storing the canal water in the farm pond instead of directly applying to the field using the free flooding method is alternate solution to overcome the disadvantages of the canal irrigation system. Once the canal water storing in the pond, it increases the possibilities to use the advance irrigation system like drip, subsurface, sprinkler etc. to enhance water use efficiency. The comparative study between the canal water directly applying for the field and canal water storing in the farm pond then use for irrigation, executed through the field experiments carried out on the grape orchard during a period April 2013 to March 2016. Results have been evaluated based on grape yield, water-productivity, berry size, and biomass. Water productivity $\left(\mathrm{kg} \cdot \mathrm{m}^{-3}\right)$ with respect to water delivery to crop through the pond irrigation method was found 37\% higher than the canal irrigation method during the study period. Based on the results, this study recommended the use of the farm pond to store the canal water and use it as per crop demand using advance irrigation systems.
\end{abstract}

Key words: agro climatic zone, canal irrigation, evapotranspiration, farm pond, table grape, water productivity

\section{INTRODUCTION}

Table grape is one of the fruits which contribute the rich in vitamin $\mathrm{C}$ those fulfilling the requirements of the human body [FELLERS et al. 1990]. Complete food always demand of all contaminants requires to body, so in complete food table grape is important fruit [PAPADEMETRIOU, DENT 2001]. For grape production, there is regular water demand throughout the year. At water scarcity prone areas, production of grapes is difficult. Hence, to supply regular water there is a demand of such supplemental irrigation system which will ensure continuous water supply in drought prone areas [AYARS et al. 1999]. Most of the researchers have been concluded that supplemental irrigation systems show significant improvements in crop production in many regions of the world [MUSHTAQ et al. 2006; NGIGI et al. 2005]. Maximizing production and enhancing water use efficiency are more feasible objective using on-farm water management in arid farming systems [OWEIS, HACHUM 2006]. A number of management options are available at the farm scale to increase the water use efficiency. Some of these options are rotations of the crop to use better rainfall and creation of farm ponds to store excess rainfall for irrigation [FREEBAIRN et al. 1986]. Onfarm facilities of storage water can be useful to satisfy the variable diurnal water demand of the crop during a required period and simultaneously prevent water wastage [MEHTA, GoTO 1992]. The use of water effi- 
ciently has becoming a global concern due to enhance food production requirements with limited water availability [IPCC 2007]. Though the farm pond is used in the rainfed area, it is also useful in irrigated agriculture to store canal water in it. The farm pond is giving a quick response to crop water demand, thus the delay in time for conveyance will be avoided. There are at least two critical issues related to irrigation one is the crop water requirement and another is its application to the crop. At the time of limited water availability, it is difficult to manage consistency in the crop yield [GARUDKAR et al. 2011].

The prime objective of this work is related to the application of water to the crop, using assessment of the performance of the pond irrigation system (Ip) and the traditional canal irrigation system (Ic). Canal irrigation (Ic) is the adopted irrigation system in the study area, but it has got several serious disadvantages such as mismatch between rotation schedules and crop water demand, water can apply using a free flooding irrigation method, though modern irrigation techniques available [PALMER et al. 1991]. Alternatively, the pond irrigation system (Ip) is the on-farm system, which stores water mainly from canal water for its ready use. It has got several advantages such as economical in construction, due to simple geometry, tailored to fit any site conditions and allow possible use of efficient irrigation method [MEHTA, GOTO 1992]. A comparative study between the two irrigation systems has been executed through the field experiments carried out during April 2013 to March 2016 based on yield, water productivity, berry size, and biomass in the grape orchard.

\section{MATERIALS AND METHODS}

\section{STUDY AREA}

This study describes a three-year experimentation work (April 2013-March 2016] carried out on the grape orchard (Vitis vinifera cultivars), located at the Nashik district, India, at $20^{\circ} 04^{\prime} 19^{\prime \prime} \mathrm{N}$ and $73^{\circ} 54^{\prime} 05^{\prime \prime} \mathrm{E}$, and the altitude is $585 \mathrm{~m}$ above mean sea level. The study area was a flat terrain, semiarid climatic condition, average annual cumulative rainfall of $650 \mathrm{~mm}$ and maximum dry period months were January to May as per recorded data with Indian Metrological Department (IMD), Nashik district for the period of 1980-2010 [SHARMA 2014]. The monthly mean temperature ranges minimum $13.4^{\circ} \mathrm{C}$ in January and maximum $36.4^{\circ} \mathrm{C}$ in May for the period of $1980-2010$. In the study area winter was mild and there was no risk of frost, as the absolute minimum temperature was greater than the $4^{\circ} \mathrm{C}$. Mean wind speed was high in the month of June $7 \mathrm{~m} \cdot \mathrm{s}^{-1}$ and low in month January $1.0 \mathrm{~m} \cdot \mathrm{s}^{-1}$. Monthly mean of relative humidity was $54.45 \%$ and minimum values were in warmer months. The climatic conditions of the area are described on the basis of aridity indices and found out which area is semiarid [ROSSI, CANCELIERE 2002].

From April 2013 to March 2016 climatic data was collected regularly from the Ozar weather station, which is located $2.1 \mathrm{~km}$ from experimental field as summarised in the Figure 1. Precipitation mainly occurs in the months of June to October. Evidence of precipitation was observed in November due to the post monsoon, but it was harmful for grape yield as it

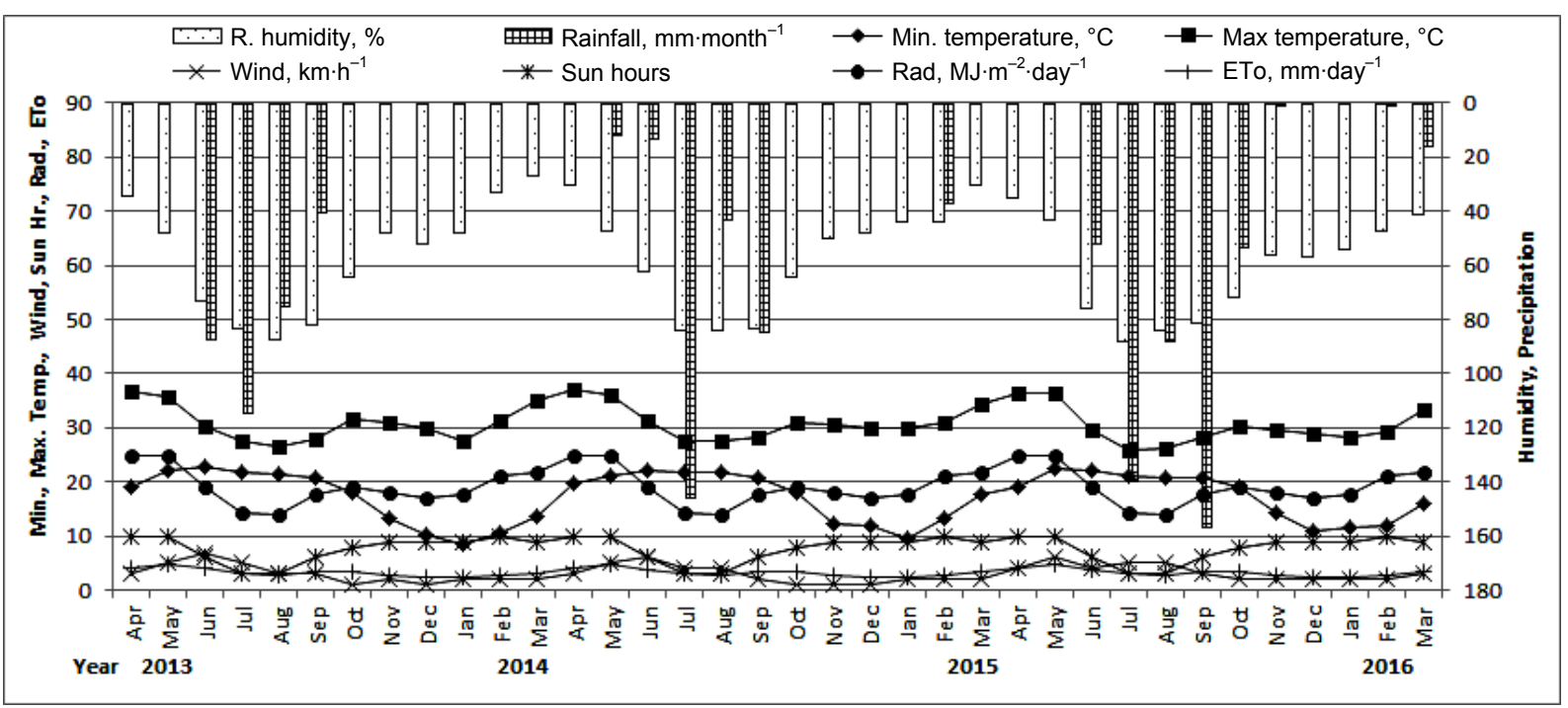

Fig. 1. Measurement of the climatic parameters like relative humidity $(\%)$, precipitation $(\mathrm{mm})$, temperature $\left({ }^{\circ} \mathrm{C}\right)$, the wind speed $\left(\mathrm{km} \cdot \mathrm{h}^{-1}\right)$, sun hours, radiation $\left(\mathrm{MJ} \cdot \mathrm{m}^{-2} \cdot \mathrm{day}^{-1}\right), E T o\left(\mathrm{~mm} \cdot \mathrm{day}^{-1}\right)$ during study period April 2013 to March 2016; source: own study

was harmful for grape berry setting. November to May precipitation occurred rarely, noted in February in year 2015 and in March 2016. It was revealed from the data that during March to May temperature is high, no precipitation and low humidity resulted in grater crop water demand. Whereas during June to October temperature was low, precipitation and humidity was high resulted in low crop water demand. 
In November to February there was low temperature, rear rainfall and low humidity resulted in moderate crop water demand.

\section{ANALYSIS OF THE CROP WATER REQUIREMENT USING CROPWAT-8.0 MODEL}

The water requirement of grape crop was calculated using CROPWAT-8.0 model. The prime purpose of the CROPWAT-8.0 was to calculate irrigation scheduling and crop water demand on the basis of input of data provided to the user in the prescribed format [GHAMARNIA et al. 2012]. CROPWAT-8.0 calculation procedures were based on FAO guidelines [ALLEN et al. 1998]. This allows the user to easily account for different soil, climatic and crop data in the calculation of crop water demand, irrigation schedules and scheme supplies [CONSOLI, BARBAGALlO 2012]. Penman-Monteith theory was used to calculate reference evapotranspiration (ETo). Evapotranspiration of the crop can be calculated with the help of climatic parameters, crop resistance and air resistance factors, evapotranspiration of the crop using Penman-Monteith approach. Although there was lack of information regarding any crop, Penman-Monteith models use to find the reference evapotranspiration (ETo). The determined ratio of ETc.ETo ${ }^{-1}$ experimentally called as crop coefficient $(K c)$. Further it was used for estimating ETc from ETo. Irrigation volumes equal to evapotranspiration and appropriated crop coefficients ranging from 0.60 to 0.75 were found best for vineyards for variety Italia [NETZER et al. 2009]. On experimental site grape plants was of $2-5$ years age with $\mathrm{T}$ shape and $\mathrm{Y}$ shape training so $K c$ was taken in the range of $0.65-0.75$ as matching the climatic conditions of referred literature [MONTORO et al. 2008]. Crop stages were taken as April pruning to October pruning and October pruning to harvesting. Crop evapotranspiration can be evaluated using equation 1 .

$$
E T c=E T o \cdot K c
$$

It is called as the approach of crop coefficient to evaluate evapotranspiration of the crop. PenmanMonteith [ALLEN et al. 1998] relation gives consistent performance and fairly accurate results in arid as well as humid climates.

The net irrigation water requirement (NIR) is equivalent to the difference of crop evapotranspiration $(E T c)$ and effective precipitation $\left(P_{e f}\right)$. Effective precipitation $\left(P_{e f}\right)$ was finding using the CROPWAT-8.0 model, based on the theory of dependable rainfall [DASTANE 1974; DOORENBOS, KASSSAM 1979] as given in equation 2 and 3.

$$
\begin{aligned}
& P_{e f}=0.6 P-10 \text { for } P_{\text {month }} \leq 70 \mathrm{~mm} \\
& P_{e f}=0.8 P-24 \text { for } P_{\text {month }}>70 \mathrm{~mm}
\end{aligned}
$$

Where $P_{e f}$ is the effective rainfall, $P$ is the monthly cumulative rainfall.

\section{PROPERTIES OF SOIL ON EXPERIMENTAL SITE}

Grape yield is depending on the fertilisers use and soil properties [USSAHATANONTA et al. 1996]. The organic fertiliser like decomposed cow dong and cow urine were used on the experimental site. Biochemical properties of soil are important parameters to grow grape crop. The active root zone has existed mostly in 10 to $40 \mathrm{~cm}$ below ground. Accordingly, soil sample was collected from layer $10 \mathrm{~cm}$ to $40 \mathrm{~cm}$ below ground from the four different corner of the experimental site. Physical and biochemical soil properties are very important for irrigation and crop yield. Properties of soil were tested in the National Horticulture Research and Development Center (NHRDC), Nashik. According to testing report on the experimental site soil texture was silty clay loam, water holding capacity was $0.38 \mathrm{~m}^{3} \cdot \mathrm{m}^{-3}$, and wilting point was 0.22 $\mathrm{m}^{3} \cdot \mathrm{m}^{-3}$. Biochemical properties of soil are reported in the Table 1 .

Table 1. Biochemical properties of the soil in the grape orchard in the Nashik district, India

\begin{tabular}{|c|c|c|c|c|c|c|c|}
\hline $\mathrm{pH}$ & $\begin{array}{c}\text { Electric } \\
\text { conductivity } \\
\mathrm{dS} \cdot \mathrm{m}^{-1}\end{array}$ & $\begin{array}{c}\text { Organic carbon } \\
\%\end{array}$ & $\begin{array}{c}\text { Nitrogen } \\
\mathrm{kg} \cdot \mathrm{ha}^{-1}\end{array}$ & $\begin{array}{c}\text { Phosphorus } \\
\mathrm{kg} \cdot \mathrm{ha}^{-1}\end{array}$ & $\begin{array}{c}\text { Potassium } \\
\mathrm{kg} \cdot \mathrm{ha}^{-1}\end{array}$ & $\begin{array}{c}\text { Calcium } \\
\mathrm{mg} \cdot \mathrm{kg}^{-1}\end{array}$ & $\begin{array}{c}\text { Sodium } \\
\mathrm{mg} \cdot \mathrm{kg}^{-1}\end{array}$ \\
\hline 8.41 & 0.232 & 0.99 & 508.4 & 25.50 & 336.0 & 640 \\
\hline $\begin{array}{c}\text { Calcium car- } \\
\text { bonate, } \%\end{array}$ & $\begin{array}{c}\text { Magnesium } \\
\mathrm{mg} \cdot \mathrm{kg}^{-1}\end{array}$ & $\begin{array}{c}\text { Chlorides } \\
\mathrm{mg} \cdot \mathrm{kg}^{-1}\end{array}$ & $\begin{array}{c}\text { Sulphur } \\
\mathrm{mg} \cdot \mathrm{kg}^{-1}\end{array}$ & $\begin{array}{c}\text { Copper } \\
\mathrm{mg} \cdot \mathrm{kg}^{-1}\end{array}$ & $\begin{array}{c}\text { Iron } \\
\mathrm{mg} \cdot \mathrm{kg}^{-1}\end{array}$ & $\begin{array}{c}\mathrm{Manganese} \\
\mathrm{mg} \cdot \mathrm{kg}^{-1}\end{array}$ & $\begin{array}{c}\text { Zinc } \\
\mathrm{mg} \cdot \mathrm{kg}^{-1}\end{array}$ \\
\hline 11.4 & 288 & 1.59 & 9.6 & 2.339 & 1.699 & 2.220 & 0.6724 \\
\hline
\end{tabular}

Source: own study.

\section{EXPERIMENTAL DESIGN}

The experimental setup was established on nine rows as shown in Figure 2. All grape plant was of common verity of Thomson seedless. Each experimental row has a 16 number of grape plants. Spacing between rows was $2.4 \mathrm{~m}$ and spacing between two plants was $1.2 \mathrm{~m}$. Canal water brought to the plot through the minor of the canal. Canal water applied to four rows directly using the free flooding method having a $\mathrm{T}$ and $\mathrm{Y}$ trellis structure, whereas reaming four rows irrigated through the pond using the drip irrigation system. Canal water stored in the pond made to pass through $1.5 \mathrm{~m} \times 1.5 \mathrm{~m} \times 0.6 \mathrm{~m}$ grit chamber to prevent silt directly entering in the pond and concrete pipe of $40 \mathrm{~cm}$ diameter with $25 \mathrm{~mm}$ steel mesh was provided. Water was supplied to plants using electric pump through the PVC pipe line with regulating 
valve, screen filter, $16 \mathrm{~mm}$ diameter laterals and $8 \mathrm{dm}^{3} \cdot \mathrm{h}^{-1}$ discharge emitters.

Irrigation water applies using canal though minors and then distributary. Distributary was a design for the discharge of $1 \mathrm{~m}^{3} \cdot \mathrm{s}^{-1}$, but sometime discharge may vary with time and weather conditions. To measure the exact distributary discharge v-notch was inserted at the field. The average flow was observed 0.6 $\mathrm{m}^{3} \cdot \mathrm{s}^{-1}$. Total water applied was $30 \cdot 10^{5} \mathrm{~m}^{3} \cdot \mathrm{ha}^{-1}$ per rotation.

Whereas in pond irrigation system water was applied according to the net irrigation water demand (NIR), calculated using CROPWAT-8.0 model. Each grape plant was two emitters of discharge $8 \mathrm{dm}^{3} \cdot \mathrm{h}^{-1}$. Discharge of emitters was directly proportion to the pressure in laterals. To apply the appropriate water, pressure Vs discharge calibration was done with help of pressure meter and the measuring cylinder.

Grape trellises were two ways i.e. Y shape trellis and $\mathrm{T}$ shape trellis which were the supporting structure along with grape plant. Y shape trellis height 1.5 $\mathrm{m}$ and $\mathrm{T}$ shape trellis height $2.1 \mathrm{~m}$ and this was an important parameter for grape yield. Irrigation water supplied using the pond to $\mathrm{Y}$ shape trellis is indicated as Yp, T shape trellis as Tp, canal irrigation $\mathrm{Y}$ shape trellis as Yc, and $\mathrm{T}$ shape trellis as Tc.

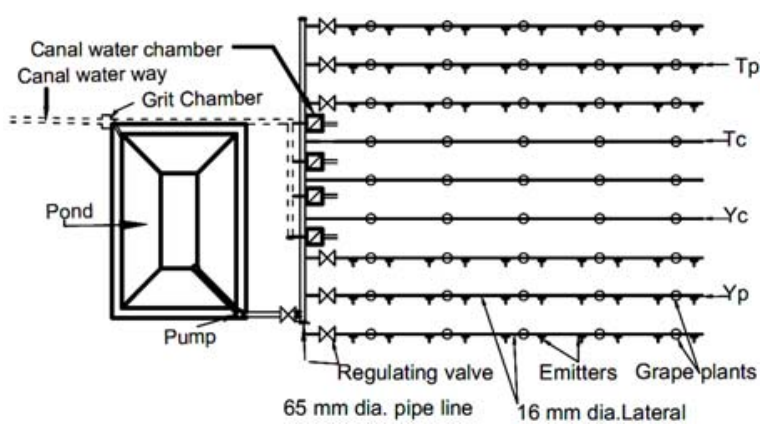

Fig. 2. Experimental layout showing the position of the pond, grape plants, emitters, and irrigation types; source: own elaboration

\section{SOIL MOISTURE MEASUREMENT USING SENSORS}

Two sensors at the different depth at the same location give more beneficial information than they place at the separate location [STEDUTO et al. 2012]. $\mathrm{EC}_{\mathrm{H} 2 \mathrm{O}}$ of Decagon Devices capacitive sensors are mounted to soil moisture measurement. The resolutions of sensors are $0.002 \mathrm{~m}$ and have a margin of error of about $2 \%$ according to the manufacturer's declaration. Two $15 \mathrm{~cm}$ probes are installed in each location.

As per Indian standards (IS2720 part 2), water moisture content of a soil mass is defined as the ratio of the mass of water in the voids to the mass of solids, as shown below in the equation (4).

$$
\theta_{v}=\frac{V_{w}}{V_{s}}
$$

where: $\theta_{v}=$ soil moisture, $\mathrm{m}^{3} \cdot \mathrm{m}^{-3} ; V_{w}=$ the volume of water, $\mathrm{m}^{3} ; V_{s}=$ the volume of soil, $\mathrm{m}^{3}$.

\section{MEASUREMENT OF YIELD, WATER PRODUCTIVITY, BERRY SIZE, AND BIOMASS}

Each plant has its unique characteristics. Measurement of peripheral plants was avoided due to some outside environmental effects. The number of bunches and weight of the bunch is varying with grape plant. At the time of harvesting, bunch weight was taken using electronics weighing balance. Berry size of each bunch was measured with berry gauging scale. Biomass was measured after cutting all sub-branches with leaf at the time of April pruning. The efficient use of irrigation water is defined as the production per grape plant per unit use of irrigation water [MARTÍNEZ, RECA 2014].

Water productivity (water use efficiency) $\left(\mathrm{kg} \cdot \mathrm{m}^{-3}\right)=$ ratio of grape yield $(\mathrm{kg})$ and volume of consumptive irrigation water use $\left(\mathrm{m}^{3}\right)$.

\section{MULTIFACTORIAL STATISTICS ANALYSIS}

Assessment of influences of considered factor on the dependent variables was carried out using multifactorial analysis and analysis of variance (ANOVA) method. There are a number of factors which effects on production grape yield, but this study only two are considered i.e. irrigation, and the shape of the trellis. In this analysis, grape yield, water-productivity, berry size, and biomass have been selected as dependent variables and Irrigation methods and trellis type considered as independent factors. Statistical analysis has been carried out using microsoft excel statistical analysis pact-2010.

\section{THE BENEFITS AND COST OF IRRIGATION SYSTEMS}

The cost of material and labour was considered subjected to market rates. In the pond irrigation system cost required to construct the pond, an establishment drip system, installation of the electric pump, and lay the fencing line was considered as the initial cost. In the canal irrigation labour charges were more to convey irrigation water as compare to the pond system. The benefit of irrigation systems was calculated using net profitable outcome after grape sell in the market. Benefit cost analysis is carried out per plant.

\section{RESULTS AND DISCUSSIONS}

\section{THE CROP WATER REQUIREMENTS AND IRRIGATION SCHEDULE}

Year wise irrigation water balance analysis for the study period is shown in Figure $3 a, b$, and c respectively. ETc is the evapotranspiration at standard conditions $(\mathrm{mm}) ; P_{e f}$ is the total rainfall $(\mathrm{mm}) ; N I R$ is 

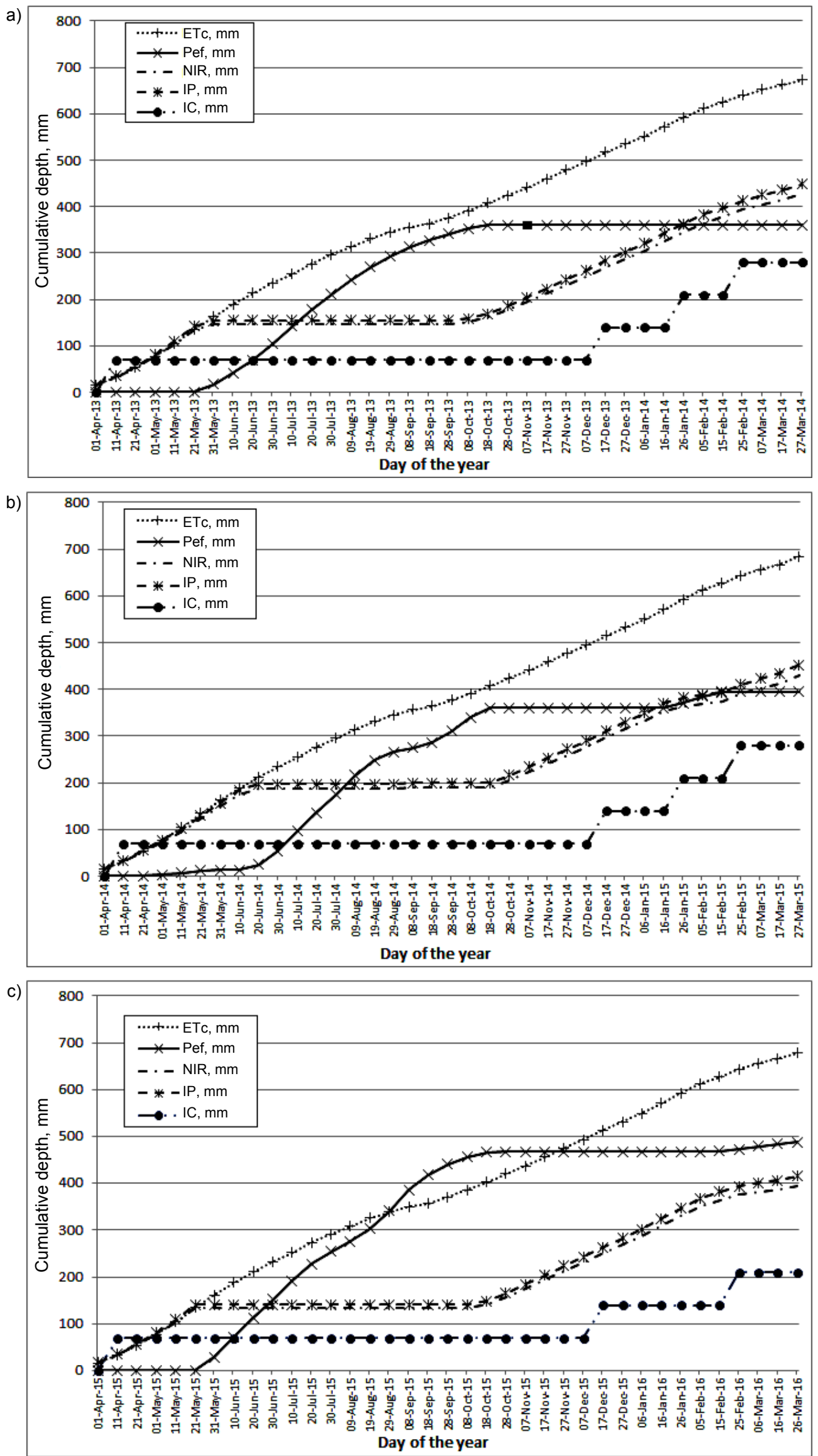

Fig. 3. Graphical representation of irrigation, water balance with the climatic parameters for: a) crop year 2013-2014; b) crop year 2014-2015; c) crop year 2015-2016; source: own study 
the net irrigation requirements ( $\mathrm{mm})$; Ip is the annual irrigation water applied using the pond ( $\mathrm{mm})$; Ic is the annual irrigation water applied using the canal (mm). Irrigation water applied using the canal (Ic) was not matching well with theoretically calculated net irrigation requirements $(N I R)$ in all three years.

The cumulative ETc under standard conditions was steady in three study years in the range of 650 to $700 \mathrm{~mm}$. Irrigating the grape based upon evapotranspiration at the four day interval in drip irrigation grape was found most economic [KovACHEV, PONDEV 1988]. The net irrigation requirement was very low in year 2015-2016 (i.e. $395 \mathrm{~mm}$ ) as compare to other two years, and this bias was due to more effective precipitation particularly on the experimental site compare to the previous two years. Corp water demand was fulfilled at the appropriate time using the pond irrigation (Ip) system. Whereas the canal irrigation system was mismatches the crop water require- ment. Only three canal rotations were scheduled in crop year 2015-2016. It created the large gap between the net water requirement and irrigation water provided using the canal. The amount of water use in the canal system was always high, but due to evaporation and infiltration effects, net water use was $70 \mathrm{~mm}$ per rotation.

\section{SOIL MOISTURE DISTRIBUTION}

Figure $4 \mathrm{a}, \mathrm{b}$ shows the results of the soil moisture $\left(\theta_{v}\right)$ at the depth of $30 \mathrm{~cm}$ and $60 \mathrm{~cm}$ with respect to irrigation water provided (IWP). Soil moisture was measured with the sensor and its output device, in last experimental crop year 2015-2016. Moisture level was maintained 0.15 to $0.33 \mathrm{~m}^{3} \cdot \mathrm{m}^{-3}$ in the pond system. In the rainy season (June to October), variations were more in moisture level, because it was totally depends on rainfall.
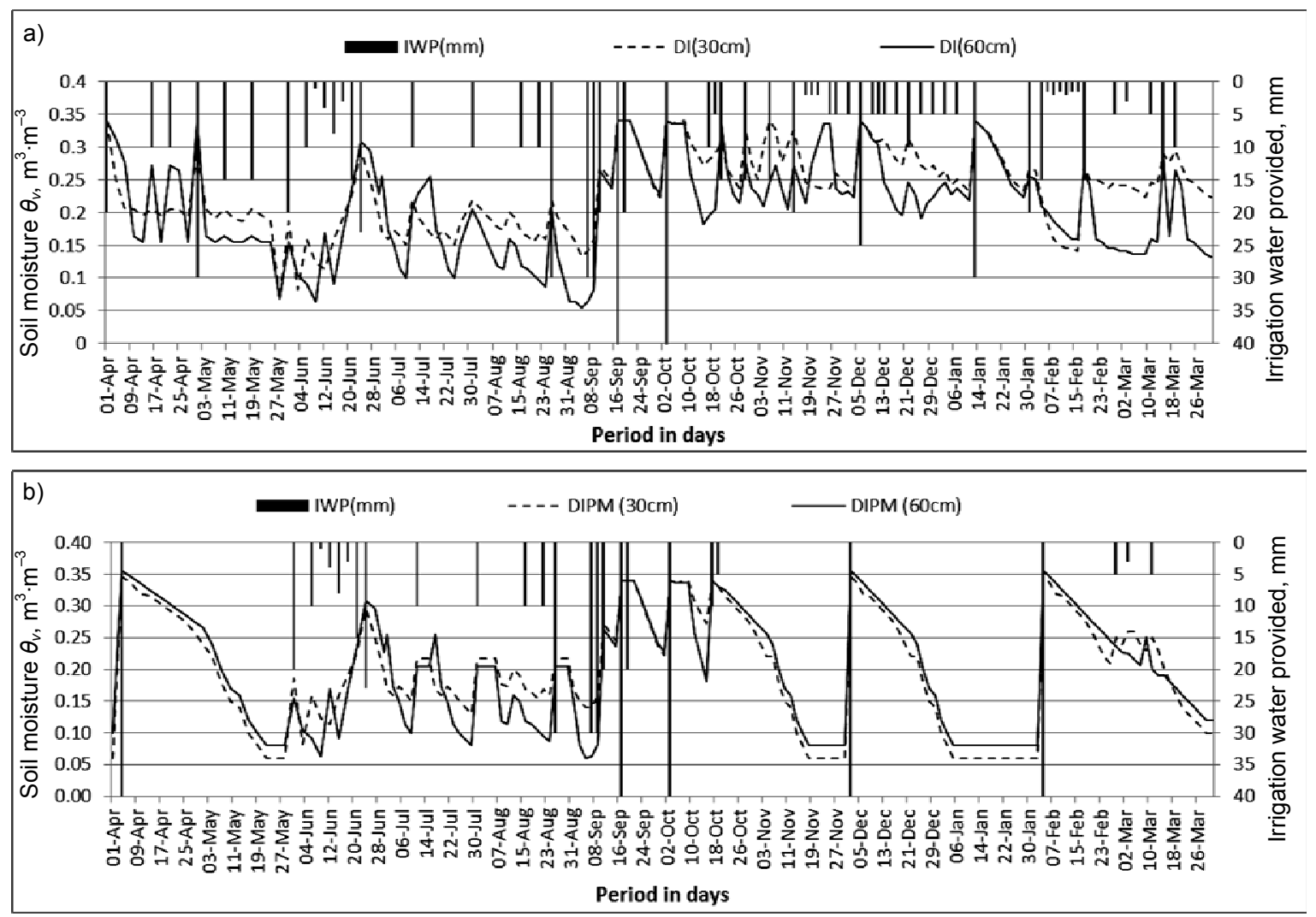

Fig. 4. Measured soil moisture $\left(\mathrm{m}^{3} \cdot \mathrm{m}^{-3}\right)$ in crop year 2015-2016 at the depth of $30 \mathrm{~cm}$ and $60 \mathrm{~cm}$ below the ground surface at the same location for (a) the pond irrigation (Ip) system; (b) the canal irrigation (Ic) system; source: own study

In case of canal irrigation system soil moisture suddenly increase at the time of canal rotation in month April, November and February. The soil moisture was continuously decreases after time passes. The $30 \mathrm{~cm}$ deep sensor was always showing low reading as compare to the $60 \mathrm{~cm}$ deep sensor. This is because, a soil evaporation upper layer is always high as compare to the deep layers. In the rainy season, from June to October, the moisture situation in the canal system and the pond irrigation system was same, both depends on rainfall only. The moisture stress occurs after 20 days of canal rotation because sensor reading was below $0.1 \mathrm{~m}^{3} \cdot \mathrm{m}^{-3}$ for the long time. The ill effect of moisture stress results decrees in grape yield. Water deficits at berry growing stages results in the greatest reduction in berry size and weight. Water deficit after irrigation had a minor effect on berry weight at maturity and berries were insensitive to water deficit during the month after harvest [MCCARTHY $1997]$. 


\section{AN IMPACT OF THE IRRIGATION METHOD AND TRELLIS STRUCTURE ON THE GRAPE YIELD}

Table 2 indicate the multifactorial analysis of variance (ANOVA) as per experimental results obtained. The sum of squares, mean of square $f$-ratio and $p$-value are calculated for all three years. $p$-value is less than $5 \%$ in all three experimental years, it means confidence intervals are $95 \%$ for irrigation methods and results are statistically significant for all three years. Irrigation methods and trellis type effects on the grape yield.

Figure 5 shows the box plot of grape yield $\left(\mathrm{kg} \cdot\right.$ plant $\left.^{-1}\right)$ for three crop years. The grape yield was 20-25\% high 2013-2014 and 2014-2015 in the pond irrigation system as compare to the canal irrigation system. In the crop year 2015-2016 grape yield increases $38 \%$ compare to the canal irrigation system due to two rotations are skipping from schedule because of insufficient storage in the dam. The pond irrigation system provided water timely results increase in grape yield in all three crop years. Compared with standard conventional irrigation techniques, one important advantage of regular irrigation is the better control of vegetative growth and increase in yield [LOVEYS et al. 2000; MCCARTHY et al. 2002]. Whereas in the contest of canal irrigation, water not provided on timely according to phenological stages of grape and it results decrees the yield.

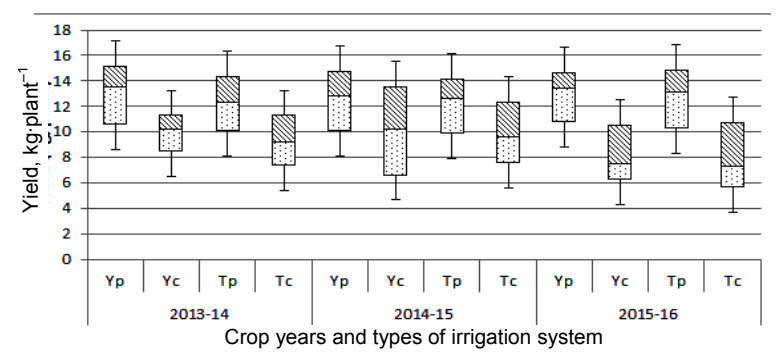

Fig. 5. Box plot of grape yield $\left(\mathrm{kg} \cdot\right.$ plant $\left.^{-1}\right)$ during crop years 2013-2014 to 2015-2016; Yp, Yc, Tp, Tc, = trellis structures; source: own study

Table 2. Analysis of variance of experimental results during crop years 2013-2014 to 2015-2016

\begin{tabular}{|c|c|c|c|c|c|c|c|c|c|c|c|c|c|c|}
\hline \multirow{2}{*}{ Parameter } & \multirow{2}{*}{ Source } & \multirow{2}{*}{$D f$} & $S S$ & $M S$ & $F$-ratio & $p$-value & $S S$ & $M S$ & $F$-ratio & $p$-value & $S S$ & $M S$ & $F$-ratio & $p$-value \\
\hline & & & \multicolumn{4}{|c|}{ 2013-2014 } & \multicolumn{4}{|c|}{ 2014-2015 } & \multicolumn{4}{|c|}{ 2015-2016 } \\
\hline \multirow{7}{*}{$\begin{array}{l}\text { Yield per } \\
\text { plant }\end{array}$} & \multicolumn{14}{|l|}{ ME } \\
\hline & $\mathrm{A}$ & 1 & 32.65 & 32.65 & 9.27 & 0.010 & 89.38 & 89.38 & 49.48 & 0.000 & 21.11 & 21.11 & 7.15 & 0.020 \\
\hline & $\mathrm{B}$ & 1 & 69.12 & 69.12 & 96.28 & 0.000 & 86.16 & 86.16 & 41.94 & 0.000 & 52.30 & 52.30 & 94.79 & 0.000 \\
\hline & \multicolumn{14}{|l|}{ Int. } \\
\hline & $\mathrm{AB}$ & 1 & 18.20 & 18.20 & 6.33 & 0.030 & 92.57 & 92.57 & 23.15 & 0.000 & 40.06 & 40.06 & 14.46 & 0.000 \\
\hline & residual & 13 & 37.38 & 2.88 & & & 51.97 & 4.00 & & & 36.00 & 2.77 & & \\
\hline & total & 14 & 55.58 & & & & 144.54 & & & & 76.06 & & & \\
\hline \multirow{7}{*}{$\begin{array}{l}\text { Water } \\
\text { produc- } \\
\text { tivity }\end{array}$} & \multicolumn{14}{|l|}{ ME } \\
\hline & $\mathrm{A}$ & 1 & 18.56 & 18.56 & 23.86 & 0.0003 & 40.92 & 40.92 & 70.25 & 0.0000 & 9.28 & 9.28 & 7.76 & 0.0155 \\
\hline & $\mathrm{B}$ & 1 & 23.54 & 23.54 & 59.64 & 0.0000 & 32.85 & 32.85 & 27.31 & 0.0002 & 20.44 & 20.44 & 60.53 & 0.0000 \\
\hline & \multicolumn{14}{|l|}{ Int. } \\
\hline & $\mathrm{AB}$ & 1 & 11.00 & 11.00 & 10.76 & 0.0060 & 35.51 & 35.51 & 23.43 & 0.0003 & 27.18 & 27.18 & 17.57 & 0.0011 \\
\hline & residual & 13 & 13.29 & 1.02 & & & 19.70 & 1.52 & & & 20.10 & 1.55 & & \\
\hline & total & 14 & 24.29 & & & & 55.22 & & & & 47.28 & & & \\
\hline \multirow{7}{*}{ Berry size } & \multicolumn{14}{|l|}{$\mathrm{ME}$} \\
\hline & $\mathrm{A}$ & 1 & 18.47 & 18.47 & 26.22 & 0.000 & 37.77 & 37.77 & $7 \mathrm{E}+31$ & 0.000 & 37.77 & 37.77 & $5 \mathrm{E}+31$ & 0.000 \\
\hline & $\mathrm{B}$ & 1 & 23.68 & 23.68 & 78.12 & 0.000 & 37.77 & 37.77 & $2 \mathrm{E}+31$ & 0.000 & 37.77 & 37.77 & $2 \mathrm{E}+31$ & 0.000 \\
\hline & \multicolumn{14}{|l|}{ Int. } \\
\hline & $\mathrm{AB}$ & 1 & 18.81 & 18.81 & 43.67 & 0.000 & 33.69 & 33.69 & $3 \mathrm{E}+31$ & 0.000 & 29.84 & 29.84 & $1 \mathrm{E}+32$ & 0.000 \\
\hline & residual & 13 & 5.60 & 0.43 & & & 0.00 & 0.00 & & & 0.00 & 0.00 & & \\
\hline & total & 14 & 24.41 & & & & 33.69 & & & & 29.84 & & & \\
\hline \multirow{7}{*}{ Biomass } & \multicolumn{14}{|l|}{$\mathrm{ME}$} \\
\hline & $\mathrm{A}$ & 1 & 5.96 & 5.96 & 13.29 & 0.003 & 2.57 & 2.57 & 6.79 & 0.022 & 3.42 & 3.42 & 21.99 & 0.000 \\
\hline & $\mathrm{B}$ & 1 & 7.41 & 7.41 & 21.96 & 0.000 & 7.33 & 7.33 & 566.53 & 0.000 & 3.82 & 3.82 & 30.64 & 0.000 \\
\hline & \multicolumn{14}{|l|}{ Int. } \\
\hline & $\mathrm{AB}$ & 1 & 2.50 & 2.50 & 2.83 & 0.117 & 3.25 & 3.25 & 5.47 & 0.036 & 6.66 & 6.66 & 58.38 & 0.000 \\
\hline & residual & 13 & 11.48 & 0.88 & & & 7.73 & 0.59 & & & 1.48 & 0.11 & & \\
\hline & total & 14 & 13.98 & & & & 10.99 & & & & 8.14 & & & \\
\hline
\end{tabular}

Explanations: $\mathrm{ME}=$ main effect, $\mathrm{A}=$ irrigation methods, $\mathrm{B}=$ trellis system, Int. = interaction, $D f=$ degree of freedom, $S S=$ sum of squares, $M S=$ mean square, $F$-ratio $=$ ratio of two scaled sums of squares, $p$-value $=$ significance.

Source: own study.

Grape yield was $7-10 \%$ higher in case of $Y$ trellis structure in all three crop years. The prime reason was the height of the $\mathrm{Y}$ trellis structure is $1.5 \mathrm{~m}$ and $\mathrm{T}$ trellis structure is the $2.1 \mathrm{~m}$. Less height of plant results high water circulation in plant body. The yearly pro- duction of biomass and potential economic yield per hectare are reduced when light strikes the vineyard floor rather than the canopy [KLIEWER 1980]. Total biomass production is directly related to the light interception of leaves. A trellis should provide the 
framework for a leaf canopy that maximizes light interception per hectare. The Y shape trellis structure results maximum plant leaf comes in contact with sunlight and wind, so there was less chance of fungal diseases. A healthy environment was created for crop growth, resulting in more yields. Whereas in $\mathrm{T}$ trellis structure due to shape, lees leaf comes in contact with light and pesticides and fungicide sprays are not cover all leafs due to more height and wind obstruction. There were chances to born a fungal disease. This situation shows fewer yields in case of $\mathrm{T}$ trellis as compare $\mathrm{Y}$ trellis, though soil conditions and climatic conditions are same in both trellises.

\section{AN IMPACT OF IRRIGATION METHOD AND TRELLIS STRUCTURE ON THE WATER PRODUCTIVITY}

$P$-value is always less than $5 \%$ in all three experimental years. The confidence intervals are $95 \%$ for irrigation methods. The trellis structure results are statistically significant for all three years as shown in the Table 2. Irrigation methods and the trellis structure show different results regarding the water productivity [SIVILOTTI et al. 2005]. It concludes that the application of greater amounts of water is not essential for plant performance and berry development. Indeed, moderate water deficit irrigation can maintain or even improve fruit quality. Both regular deficit irrigation treatments supposed a saving water of 35\% without compromising total yield and its components, while the increasing water use efficiency (about 30\%) compared with the full irrigation [CONESA et al. 2016].

The box plot of water productivity $\left(\mathrm{kg} \cdot \mathrm{m}^{-3}\right)$ for three crop years in the contest of pond irrigation and canal irrigation with $\mathrm{Y}$ shape trellis and $\mathrm{T}$ shape trellis is shown in the Figure 6 . As the water productivity is the ratio of yield to consumptive water use, it is always more in case of pond irrigation as compare to canal irrigation. Water productivity was $15-20 \%$ higher in pond irrigation as compare to canal irrigation in crop year 2013-2014 and 2014-2015. In crop year 2015-2016 water productivity $35-40 \%$ high in the pond irrigation system, due to scarcity of canal irrigation and decrease in yield. As per Figure 3, though net irrigation water provided using canal irrigation is less as compare to pond irrigation, but the

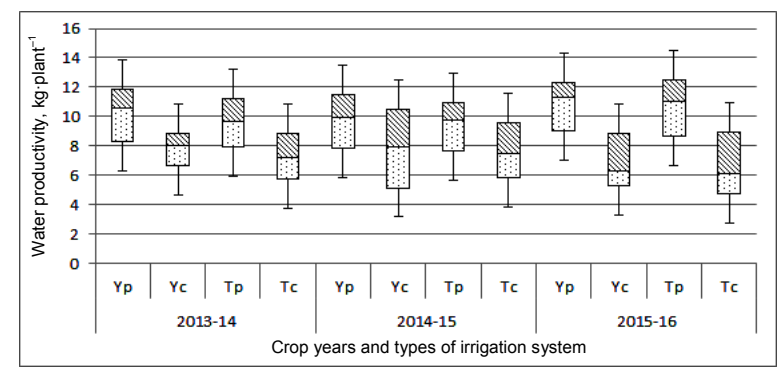

Fig. 6. Box plot of water productivity $\left(\mathrm{kg} \cdot \mathrm{m}^{-3}\right)$ during crop years 2013-2014 to 2015-2016; Yp, Yc, Tp, Tc, = trellis structures; source: own study gross water provided is more in canal irrigation as compare to pond irrigation. Maximum water was losses through evaporation and infiltration in the canal irrigation system. So water productivity is always less in the canal irrigation system. The $\mathrm{Y}$ trellis system showing 5-9\% more water productivity as compare to $\mathrm{T}$ trellis structure because of more yield in $\mathrm{Y}$ trellis structure with the same water use as reason mention in the previous section.

\section{AN IMPACT OF THE IRRIGATION METHOD AND TRELLIS STRUCTURE ON THE BERRY SIZE}

The observations were made for berry size (mm) based on irrigation methods and trellis structure (Yp, Yc, Tp, and Tc), as shown in Figure 7. As per statistical analysis, the berry size results are statistically significant due to achieving 95\% confidence level as $P$-value $<0.05$ for all three crop years.

The berry size in the pond irrigation system was observed 1-3 $\mathrm{mm}$ greater than the canal irrigation system in all three crop year. In the pond irrigation system, sufficient water was provided at berry growth phenological stage. Its results increase of the berry size. The lower supply of water and carbohydrates during the berry growth period could possibly have induced reducing berry expansion [CHAVES et al. 2010], and affecting berry growth at the end of the season. There is no significant difference regarding the berry size in case of $\mathrm{Y}$ trellis and $\mathrm{T}$ trellis.

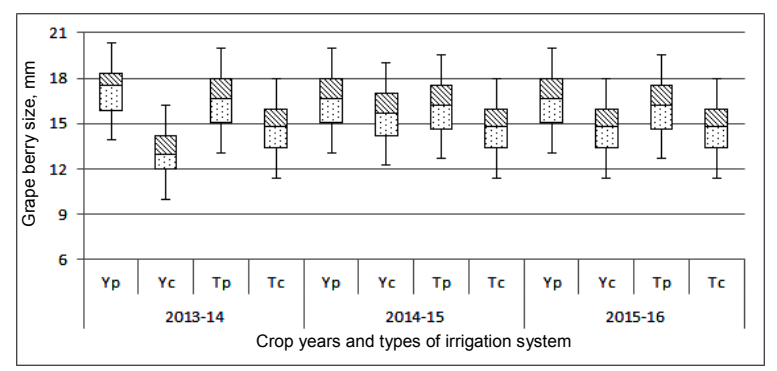

Fig. 7. Box plot of grape berry size ( $\mathrm{mm}$ ) during the crop years 2013-2014 to 2015-2016; Yp, Yc, Tp, Tc, = trellis structures; source: own study

\section{AN IMPACT OF THE IRRIGATION METHOD ON BIOMASS}

Figure 8 shows the values of biomass and Table 2 indicates the multifactorial analysis of variance (ANOVA) as per experimental results obtained. $P$-value is less than $5 \%$ so confidence intervals are $95 \%$ for irrigation methods and results are statistically significant for all three years. The biomass was 14$20 \%$ higher in the pond irrigation system as compare to the canal irrigation system. Once water provided to grape plant timely it results the good growth of leaf and branches. This suggests that biomass growth processes are very sensitive to water stress, although this also depends on the variety [MATHEWS ANDERSON 1989; ROBY, MATTHEWS 2004]. 


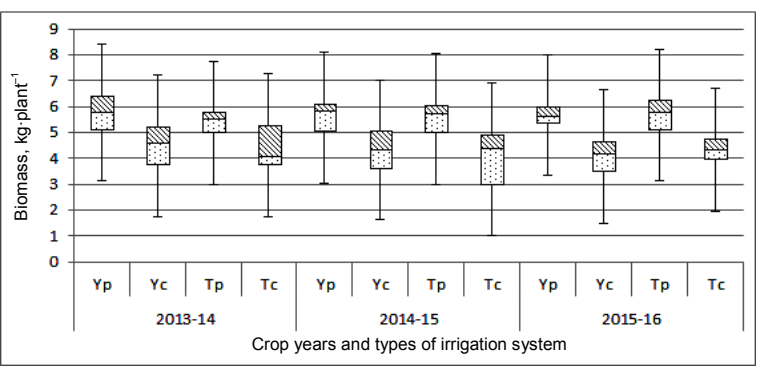

Fig. 8. Box plot of grape biomass production during the crop years 2013-2014 to 2015-2016; Yp, Yc, Tp, Tc, = trellis structures; source: own study

In case of pond irrigation system irrigation water provided to grape plant timely, so there is no stress on grape plant and appropriate growth of leaf and branches compare to canal irrigation. Accordingly, there are no changes in biomass due to $\mathrm{Y}$ trellis and $\mathrm{T}$ trellis structures.

\section{COST-BENEFIT ANALYSIS OF THE FARM POND AND THE CANAL IRRIGATION SYSTEM}

In the canal system, water given to the crop using free flooding method, so there is only requirement of labour cost [NGIGI et al. 2005]. In case of the pond system, initial investment of infrastructure has required as indicated in the Table 3. To construct the pond, financial support taking form local financial society, with annual inters rate $10 \%$. As the grape yield in pond system increase, the initial cost was recovered only in two years.

Average life of the pond was considering as 30 years. To find out benefits, yield and quality of fruit from each grape plant was considered. The yield and market rates were always high for grape grown in the

Table 3. Benefit cost analysis of the farm pond and the canal irrigation system

\begin{tabular}{|c|c|c|c|}
\hline \multirow{2}{*}{\multicolumn{2}{|c|}{ Budget item (for 1 hector area) }} & Pond & Canal \\
\hline & & \multicolumn{2}{|c|}{ INR } \\
\hline A & $\begin{array}{l}\text { Construction of the farm pond }(20 \mathrm{~h} \\
\left.\text { excavation machine @ INR } 1200 \cdot \mathrm{h}^{-1}\right)\end{array}$ & 24000 & - \\
\hline B & $\begin{array}{l}\text { \#Seepage control UV resistant plastic } \\
\text { lining sheet }\left(1050 \mathrm{~m}^{2} @ \mathrm{INR} 90 \mathrm{~m}^{2}\right)\end{array}$ & 94500 & - \\
\hline $\mathrm{C}$ & Eclectic pump with accessories & 20000 & - \\
\hline $\mathrm{D}$ & Drip irrigation system & 30000 & - \\
\hline $\mathrm{E}$ & Fencing and roofing & 25000 & - \\
\hline $\mathrm{F}$ & $\begin{array}{l}\text { Total investment cost } \\
(\mathrm{F}=\mathrm{A}+\mathrm{B}+\mathrm{C}+\mathrm{D}+\mathrm{E})\end{array}$ & 193500 & - \\
\hline G & $\begin{array}{l}\text { Recurrent cost (labour, maintenance) } \\
\text { per hectare per year + loan repayment }\end{array}$ & 30000 & 15000 \\
\hline $\mathrm{H}$ & $\begin{array}{l}\text { Net cost per year per plant (no. of } \\
\left.\text { plant } 2500 \cdot \mathrm{ha}^{-1}\right)(\mathrm{H}=\mathrm{G} / 2500)\end{array}$ & 12 & 6 \\
\hline I & Average yearly yield $\left(\mathrm{kg} \cdot \mathrm{plant}^{-1}\right)$ & 14 & 9 \\
\hline $\mathrm{J}$ & Average market rate $\left(\mathrm{INR} \cdot \mathrm{kg}^{-1}\right)$ & 60 & 30 \\
\hline $\mathrm{K}$ & Net yearly benefit (INR·plant ${ }^{-1}$ ) & 840 & 270 \\
\hline $\mathrm{L}$ & Benefit cost ratio $(\mathrm{K}=\mathrm{J} / \mathrm{H})$ & 70 & 45 \\
\hline
\end{tabular}

Explanations: INR = Indian Rupees; $\#=$ the unit cost of plastic lining varies with thickness; @ INR per $1 \mathrm{~m}^{2}$ is 60,75 and 90 for $0.8 \mathrm{~mm}$, $1.0 \mathrm{~mm}$ and $1.2 \mathrm{~mm}$, respectively.

Source: own study. pond system because of its export quality. It was observed that the benefit cost ratio 70 in the pond system and 45 in the canal system.

\section{CONCLUSIONS}

Three years experimental study was conducted to find out the performance of pond irrigation (Ip) and canal irrigation (Ic). It has been observed that the pond irrigation system fulfilling the crop water requirement on the time, whereas canal irrigation can't provide water to the crop on timely. In the pond irrigation system soil moisture was always maintained as per requirement of the crop, i.e. 0.15 to $0.35 \mathrm{~m}^{3} \cdot \mathrm{m}^{-3}$. Whereas in the canal system soil moisture decrease below $0.10 \mathrm{~m}^{3} \cdot \mathrm{m}^{-3}$ most of the time. The grape yield was $20-25 \%$ more in the pond system as compare to the canal system in all three study years. Water productivity with the pond irrigation method was found 15-20\% higher than the regular canal irrigation method. The berry size in the pond system was observed 1-3 $\mathrm{mm}$ greater than the canal irrigation system in all three crop year. The biomass $14-20 \%$ higher in the pond irrigation system as compare to the canal irrigation system. The Y trellis system showing 5$9 \%$ more water productivity as compare to $\mathrm{T}$ trellis structure because of less height of $\mathrm{Y}$ trellis and more water circulation in plant body as well as better ventilated property.

It has been observed that the benefit cost ratio more than 25 in the pond system compare to the canal system. Enhance in grape production has experimentally found in the pond system due to storing canal water in the pond instead of directly providing to the field. Finally, it is recommended that, use of the pond irrigation system will be always beneficial for the grape crop.

\section{ACKNOWLEDGMENTS}

"ATMA - Maharashtra Agriculture Department, India, and Water Users Association, Maharashtra Irrigation Department, India" have given support this work. Authors are thankful to the chairman and all members of the ATMA for their extended support and inspiration to carry out this work. Authors are also grateful to Indian Meteorological Department Pune to support this study by sharing valuable data and information.

\section{REFERENCES}

Allen R., Pereira L.S., Raes D., Smith M. 1998. Crop evapotranspiration. Guidelines for computing crop water requirements. Irrigation and Drainage Paper. No. 56. Rome. FAO. ISBN 92-5-104219-5 pp. 300.

Ayars J.E., Phene C.J., Hutmacher R.B., Davis K.R., SCHONEMAN R.A., VaIL S.S., MEAD R.M. 1999. Subsurface drip irrigation of row crops: A review of 15 years of research at the Water Management Research Laboratory. Agricultural Water Management. Vol. 42. Iss. 1 p. $1-27$.

Chaves M.M., Zarrouk O., Francisco R., Costa J.M., SAntos T., Regalado A.P., Rodrigues M.L., Lopes 
C.M. 2010. Grapevine under deficit irrigation: hints from physiological and molecular data. Annals of Botany. Vol. 105. Iss. 5 p. 661-676.

CONESA M.R., FAlagÁn N., DE la Rosa J.M., Aguayo E., DOMINGo R., PASTOR A.P. 2016. Post-veraison deficit irrigation regimes enhance berry coloration and healthpromoting bioactive compounds in 'Crimson Seedless' table grapes. Agricultural Water Management. Vol. 163 p. 9-18.

Consoli S., Barbagallo S. 2012. Estimating water requirements of an irrigated mediterranean vineyard using a satellite-based approach. Journal of Irrigation and Drainage Engineering. Vol. 138. Iss. 10 p. 896-904.

DASTANE N.G. 1974. Effective rainfall in irrigated agriculture. Irrigation and Drainage Paper. No. 25. Rome. FAO. ISBN 92-5-100272-X pp. 62.

DoOREnBOS J., KASSSAM A.H. 1979. Yield response to Water. Irrigation and Drainage Paper. No. 33. Rome. FAO. ISBN 92-5-100744-6 pp. 193.

Fellers P.J., Nikdel S., LeE H.S. 1990. Nutrient content and nutrition labeling of several processed Florida citrus juice products. Journal of the American Dietetic Association. Vol. 90. Iss. 8 p. 1079-1084.

FreEbairn D.M., Wockner G.H., Silburn D.M. 1986. Effects of catchment management on runoff, water quality, and yield potential from vertisols. Agricultural Water Management. Vol. 12. Iss. 1-2 p. 1-19.

GARUdKAR A.S., RASTOGI A.K., EldHO T.I., GoRANTIWAR S.D. 2011. Optimal reservoir release policy considering heterogeneity of command area of elitist genetic algorithm. Journal of Water Resource Management. Vol. 25 p. 3863-3881.

Ghamarnia H., ArJi I., SePehri S., NorozPour S., KhODAEI E. 2012. Evaluation and comparison of drip and conventional irrigation methods on sugar beets in a semiarid region. Journal of Irrigation and Drainage Engineering. Vol. 362. Iss. 1 p. 90-97.

IPCC 2007. An assessment of the Intergovernmental Panel on Climate Change. Climate Change: Synthesis Report. 4 p. $26-40$.

IS2720. 1973. Part-2. Indian standard methods of test for soils, determination of water content. Rev. 2 p. 5-7.

KLIEWER W.M. 1980 Vineyard canopy management - review. In: Proceedings of the University of California, Davis Grape and Wine Centennial Symposium. University of California Press, Berkeley p. 342-352.

Kovachev V., PondeV K. 1988. Determination of optimum drip irrigation regime for cultivar Pamid. Rasteniev' dni Nauki. Vol. 25(5) p. 86-90.

Loveys B.R., Stoll M., Dry P.R., Mccarthy M.G. 2000. Using plant physiology to improve the water use efficiency of horticultural crops. Acta Horticulturae. Vol. 537 p. 187-197.

MARTíneZ J., RECA J. 2014. Water use efficiency of surface drip irrigation versus an alternative subsurface drip irrigation method. Journal of Irrigation and Drainage Engineering. Vol. 745. Iss. 1 p. 733-743.

Mathews M.A., ANDERSON M.M. 1989. Reproductive development in grape (Vitis vinifera $\mathrm{L}$.): Responses to seasonal water deficits. American Journal of Enology and Viticulture. Vol. 40 p. 52-60.

MCCARTHY M.G. 1997. The effect of transient water deficit on berry development of cv. Shiraz (Vitis vinifera L.). Australian Journal of Grape and Wine Research. Vol. 3. Iss. 3 p. $102-108$.
McCarthy M.G., Loveys B.R., Dry P.R., Stoll M. 2002. Regulated deficit irrigation and partial root zone drying as irrigation management techniques for grapevines. Deficit irrigation practices. FAO Water Reports. No. 22 p. 79-87.

Mehta B.K., Goto A. 1992. Design and operation of onfarm irrigation ponds. Journal of Irrigation and Drainage Engineering. Vol. 118. Iss. 5 p. 1388-1403.

Montoro A., López UrRea R., Mãnas F., LÓPez Fuster P., Fereres E. 2008. Evaporation of grapevines measured using a weighing lysimeter in La Mancha, Spain. Acta Horticulturae. Vol. 792 p. 459-466.

Mushtaq S., Dawe D., Hong Lin, Moya P. 2006. An assessment of the role of ponds in the adoption of watersaving irrigation practices in the Zhanghe Irrigation System, China. Agricultural Water Management. Vol. 83 p. 100-110.

Netzer Y., Yao C.R., Shenker M., Bravdo B.A., SCHWARTZ A. 2009. Water use and the development of seasonal crop coefficients for Superior Seedless grapevines trained to an open-gable trellis system. Irrigation Science. Vol. 27. Iss. 2 p. 109-120.

Ngigi S.N., SAVeniJe H.H.G., ThOMe J.N., Penning DE VRIES F.W.T. 2005. Agro-hydrological evaluation of on-farm rainwater storage systems for supplemental irrigation in Laikipia district, Kenya. Agricultural Water Management. Vol. 73 p. 21-41.

Oweis T., HACHUM A. 2006. Water harvesting and supplemental irrigation for improved water productivity of dry farming systems in West Asia and North Africa. Agricultural Water Management. Vol. 80. Iss. 1-3 p. 57-73.

Palmer J.D., Clemmens A. J., Dedrick A.R. 1991. Field study on irrigation delivery performance. Journal of Irrigation and Drainage Engineering. Vol. 117. Iss. 4 p. $567-577$.

PAPADEMETRIOU M.K., DenT F.J. 2001. Grape production in the Asia-Pacific region. Bangkok, Thailand. Food and Agriculture Organization of the United Nations, Regional Office for Asia and the Pacific. No. 7 pp. 104.

Roby G., Matthews M.A. 2004. Relative proportions of seed, skin and flesh, in ripe berries from Cabernet Sauvignon grapevines grown in a vineyard either well irrigated or under water deficit. Australian Journal of Grape and Wine Research. Vol. 10 p. 74-82.

Rossi G., Cancelliere A. 2002. At-site and regional drought identification by Redim model. In: Tools for drought mitigation in Mediterranean regions. Eds. G. Rossi, A. Cancelliere, L.S. Pereira, T. Oweis, M. Shatanawi, A. Zairi. Ser. Water Science and Technology Library. Vol. 44. New York. Springer p. 37-54.

SHARMA J.R. 2014. Water resources department - Godawari basin. Report of government of India. Ver. 2 p. 10-16.

Sivilotti P., Bonetto C., Paladin M., Peterlunger E. 2005. Effect of soil moisture availability on Merlot: From leaf water potential to grape composition. American Journal of Ecology and Viticulture. Vol. 56 p. 9-18.

Steduto P., Hsiao T.C., Fereres E., Raes D. 2012. Crop yield response to water. Irrigation and Drainage Paper. No. 66. Rome. FAO. ISBN 978-92-5-107274-5 pp. 500.

USSAHATANONTA S., JACKSON D.I., ROWE R.N. 1996. Effect of nutrient and water stress on vegetative and reproductive growth in Vitis vinifera L. Australian Journal of Grape and Wine Research. Vol. 2. Iss. 2 p. 64-69. 


\section{Sharad J. KADBHANE, Vivek L. MANEKAR}

\section{Badania eksperymentalne w winnicy: Porównanie efektów nawadniania dwoma systemami}

\section{STRESZCZENIE}

Winorośl (odmiany Vitis vinifera) jest główną uprawą w dystrykcie Nashik w Indiach. Wymaga ona całorocznych nawodnień dostosowanych do chwilowego zapotrzebowania roślin. Na badanym obszarze stosuje się nawadnianie grawitacyjne, polegające na bezpośrednim dostarczaniu wody transportowanej kanałem pod uprawy winorośli. Metoda ta ma kilka wad, takich jak: niedopasowanie harmonogramu zalewów z potrzebami roślin, złożony system rozprowadzania wody i ograniczone możliwości stosowania wydajnych metod nawodnień. Przechowywanie wody dostarczonej kanałem w stawach zamiast bezpośredniego wylania na pola umożliwia ograniczenie wad nawadniania grawitacyjnego. Retencjonowanie wody w stawach umożliwi stosowanie zaawansowanych i wodooszczędnych sposobów nawadniania, takich jak: nawodnienia kroplowe, podpowierzchniowe lub deszczowniane. Porównawcze badania nad nawadnianiem bezpośrednio wodą z kanału i wodą wstępnie przetrzymywana w stawach prowadzono w okresie od kwietnia 2013 do marca 2016 r. Rezultaty oceniano na podstawie produktywności wody, plonu winogron, wielkości gron i biomasy. Produktywność wody $\left(\mathrm{kg} \cdot \mathrm{m}^{-3}\right) \mathrm{dostar}-$ czanej pod uprawy za pośrednictwem stawu była o 37\% większa niż produktywność wody aplikowanej bezpośrednio z kanału. W oparciu o wyniki badań zalecono wykorzystanie stawów w gospodarstwie do przetrzymywania wody z kanału i zastosowanie jej zgodnie z wymaganiem roślin, stosując zaawansowane systemy irygacji.

Słowa kluczowe: ewapotranspiracja, nawodnienia, produktywność wody, stawy w gospodarstwie, strefy agroklimatyczne, winorośl 